\title{
Plant Community Traits of Shohada Protected Area, West Azerbijan, Iran
}

\author{
Abdollah HASSANZADEH GORTTAPEH ${ }^{1)}$, Lala MALK MOHAMADI ${ }^{2)}$ \\ 1) Agricultural and Natural Rsource Research Institute,West Azerbijan, Iran; ahassanzadeh_g@yahoo.com (corresponding author) \\ ${ }^{2)}$ Urmia University, Faculty of Sciences, Department of Biology, West Azerbijan, Iran
}

\begin{abstract}
Shohada Protected Area, consisting of Shohada Valley and it's adjacent areas with an area of 577 hectares is located in south of Urmia, and is known as an important natural plant station of Urmia. It is studied with respect to the important factors which influence the vegetation cover in whole, particularly, with regard the composition and formation of plant communities. To study the area, BrownBlanquet's method was used. Plant samples were taken from 77 sample plots. The study resulted in recognition of four herbaceous types and seven shrub types in the studied area. In addition, the investigation led to the fact that the most important factors which influence the vegetation cover, are: geographical orientation, altitude, gradient and soil texture. The study also resulted in preparation of a colored vegetation map with a scale of 1:20000.
\end{abstract}

Keywords: type, cover, plant community, biodiversity, forest, Shohadao valley

\section{Introduction}

Quantitative and qualitative investigation of plants and recognition of existent vegetation cover and environmental factors such as land resources, soil and climate, as altogether known as ecological conditions, is needed to determine the trend of the vegetation cover for maintaining and conserving vegetation cover and so being able to optimize management and reach a sustainable development (Naseri et al., 1999). An important precondition for the above mentioned aim is having a protected area which at least for a few years will be out of the effects of external factors, particularly human interactions. Therefore, the studied area was selected as a protected area for recent research. The outcome of this study can be useful in managing natural resources (Fallah, 1999). Classification of plant communities and general community types has resulted from geobotanical researchs by Hamboldt (1805); Schow (1823); Heer (1835); Grisebach (1838); (Asri, 1995). Some of the studies with reference to phytosociology and plant ecology researchs during recent years are listed below: Eco-phytosociological evaluation of vegetation cover of Dena (Kokhdan, 2002), Phytosociology of Forests in eastern Ardabil (Taimurzadeh et al., 2003) Investigation of the plant communities of protected area in north West of Khorramabad (Mehrina et al., 2003), Eco-Phytosociological evaluation of Elikaand Dona Watershed of Central Alboorz (Nazarian, 2003), Phytocociology of Kolahghazi National Park (Khageaddin, 2000). In protected areas, determination of vegetation cover and classification of different plant types is not only is useful as a basic ecological investigation of the area, but is a suitable factor in the evaluation or even prediction of the future, which can lead to a better and more proper management of the area (Malayeri, 1984). Ecological and phytosociological studies investigate the relationship between different ecological factors and the distribution of plant communities, which in turn results to scientific and practical suggestions for improving the studied area (Batuli, 1997). This study mainly follows recognition of biodiversity and difference of habitats, which is the result of ecological difference of whole conditions and biotic and non-biotic resources. Overall, the main goals of the recent study are as follows:

1-Recognition of existent plant assemblies in studied area

2-Evaluation of the effects of environmental factors which cause the formation of assemblies

3-Developing the vegetation cover map of studied area as a base for assessing succeeding trends.

\section{Materials and methods}

The studied area is situated between $37^{\circ} 15^{\prime}$ to $37^{\circ} 20^{\prime}$ Northern latitude and $45^{\circ} 5^{\prime}$ to $45^{\circ} 10^{\prime}$ Eastern longitude, it's lowest and the highest heights are of 1420 and 2280 meters. Plant community studies in area have been done from late April to 2005 until the mid of September 2006. Present study used the Brown-Blanquet's methods (BraunBlanquet, 1932). Initially, the studied area is limited on the topographical map to a region of 1:50000 scale. Secondary, the limited area on the map is adapted to the 
30

physical situation on the field. Field studies were done by using floristic-physionomic method (Muller-Dombois, 1974), which led to the recognition of plant formations and relocating their locations on the map roughly. Then, by using a quadrate minimum area within the plots, plant sampling was done (Asri, 1995). For trees and shrubs, quadrate dimensions were $15 \mathrm{~m} \times 15 \mathrm{~m}$, and for herbs $2 \mathrm{~m}$ x $2 \mathrm{~m}$. Sample plots are located randomly and systematically within plant assemblies. According to homology of plant assemblies and their area, 5-7 sample plots are randomly located within each plant unit. Within each sample plot the name of plant species (coding unknown species), canopy cover for each existent species and their numbers are measured and recorded. Meanwhile, for each sample plot, slope direction, slope steepness, and altitude from sea level were also recorded. For comparison of soil samples of plant communities, for each plant assembly three soil profile were developed on dominant slope. Finally, soil samples were collected and transported to the laboratory for some analyses, such as evaluation of $\mathrm{pH}$, texture, structure and colour.

\section{Developing plant map of studied area}

To develop a plant map of the studied area, firstly, a 1:50000 topographical map is scanned and digitalized, then it's boarders are carefully digitalized, considering hydrological units and water ways and contour lines by using the software Arc view 3.2, Ilwise 2, which leads to the developing of physiographic map of area. Finally, mixing hypsometric, slope facing and slope direction maps by using proper software results in the plant map of the studied area (Fig. 1, 2, 3, 4).

\section{Results and disscusion}

Present study resulted in the fact that there are four herbal types and seven shrub types in the studied area, as follows:

\section{1-Salix alba L.}

This community covers the area about 9.4 hectares in the east of the studied area, on the banks of Balanech river (Fig. 1). It is located at an altitude of $1420 \mathrm{~m}$, with sandy-clay texture, granular structure which is firm and has brown-grayish color with a $\mathrm{pH}$ of 7.8. It's soil is also deep and has a slope facing mainly to the northeast. Canopy cover is about $80 \%$, sand and gravel is about $10 \%$, litter about $3 \%$, unprotected and clear soil about $7 \%$, with a positive succession rate (Fig. 5). The main species of this type includes:

$\begin{array}{ll}\text { Salix alba } & 61 \% \\ \text { Juglans regia } & 7 \% \\ \text { Fraxinus rotundifalis } & 6 \% \\ \text { Rosa canina } & 4 \% \\ \text { Other species } & 2 \%\end{array}$

2-Acer monspessulanum L. subsp. cinerascens (Boiss.) Yaltirik.-Amygdalus pabotii Browicz. - Pistacia atlantica Desf subsp. Kurdica (Zohary) Rech.f.

This community covers an area of 169 hectares, which is the most extended type (Fig. 1). It is also located at an altitude of $1420 \mathrm{~m}$ to $1940 \mathrm{~m}$, and its slope steepness ranges from $40 \%$ to $60 \%$, which is facing to the east. Its surface soil is of $57 \mathrm{~cm}$ deep with cubic structure and has a $\mathrm{pH}$ of 8. Soil color is reddish-brown and with loamy-clay texture. Canopy cover is about 60\%, sand and gravel about 30\%, litter around $5 \%$, clear soil about $5 \%$, altogether this type has positive succession rate (Fig. 6). This part of the study area includes the following species:

$\begin{array}{ll}\text { Acer monspessulanum } & 20 \% \\ \text { Amygdalus pabotii } & 10 \% \\ \text { Pistacia atlantica } & 6 \% \\ \text { Thymus kotschyanus } & 9 \% \\ \text { Cerasus mahaleb } & \\ \text { Poabulbosa } & 3 \% \\ \text { Prangos uloptera } & 7 \% \\ \text { Astragalus mollis } & 3 \% \\ \text { Bromus tectorum } & 2 \% \\ \text { Other species } & \end{array}$

\section{3-Hordeum bulbosum L.}

This community covers the area of about 19.38 hectares in the east of the study area, on the banks of Balanech river (Fig. 1). It is located at an altitude of $1420 \mathrm{~m}$ to 1520 $\mathrm{m}$, and it's slope steepness ranges from $20 \%$ to $40 \%$, which is facing to the east. Its surface soil is of $60 \mathrm{~cm}$ deep with granular structure which is firm and its $\mathrm{pH}$ is 7.8. Soil color is brown and with loamy texture. Canopy cover is about $100 \%$, sand and gravel about $0 \%$, litter around $0 \%$, clear soil about $0 \%$, altogether this type has positive succession rate (Fig. 7). The main species of this type includes:

$\begin{array}{ll}\text { Hordeum bulbosum } & 49 \% \\ \text { Medicago sativa } & 13 \% \\ \text { Gundelia tournefortii } & 8 \% \\ \text { Aegilops cylindrica } & 6 \% \\ \text { Taeniatherum crinitum } & 5 \% \\ \text { Rumex tuberosus } & 4 \% \\ \text { Bromus danthoniae } & 7 \% \\ \text { Achillea millefolium } & 6 \% \\ \text { Teucrium polium } & \\ \text { Poabulbosa } & \\ \text { Other species } & 2 \%\end{array}$

4-Thymus kotschyanus Boiss.- Festuca arundinacea Schreb.

This community covers an area of 6.49 hectares in north and north-west, with slopes facing the study area, near Balanech river (Fig. 1).

It is located at an altitude of $1440 \mathrm{~m}$ to $1560 \mathrm{~m}$, and it's slope steepness ranges from $40 \%$ to $60 \%$. Its surface soil is of $73 \mathrm{~cm}$ deep with cubic structure and its $\mathrm{pH}$ is 7.4 . In addition, soil color is reddish brown and with loamy-clay 
texture. Canopy cover is about $70 \%$, sand and gravel about $0 \%$, litter around $5 \%$, clear soil about $15 \%$, altogether this type has a positive succession rate (Fig. 8). The main species of this type includes:

$\begin{array}{lc}\text { Thymus kotschyanus- } & 40 \% \\ \text { Thymus migricus } & \\ \text { Festuca arundinacea } & 10 \% \\ \text { Bromus tomentellus } & 4 \% \\ \text { Teucrium polium } & 6 \% \\ \text { Poa bulbosa } & \\ \text { Achillea millefolium } & \\ \text { Dactylis glomerata } & 5 \% \\ \text { Hordeum bulbosum } & \\ \text { Eryngium billardieri } & 4 \% \\ \text { Stipa barbata } & \\ \text { Other species } & 1 \%\end{array}$

5-Amygdalus pabotii Browicz. - Acer monspessulanum L. subsp. cinerascens (Boiss.) Yaltirik.

This community covers an area of 12.21 hectares with a northern slope facing (Fig. 1).

It is located at an altitude of $1580 \mathrm{~m}$ to $1800 \mathrm{~m}$, and its slope steepness ranges from $40 \%$ to $60 \%$. Its surface soil is of $22 \mathrm{~cm}$ deep with cubic structure and its $\mathrm{pH}$ is 8 . Soil color is reddish brown and with loamy-silty texture. Canopy cover is about $55 \%$, sand and gravel is about $36 \%$, litter around $4 \%$, clear soil about $5 \%$, altogether this type has a positive succession rate (Fig. 9). The main species of this type includes:

$\begin{array}{ll}\text { Amygdalus pabotii } & 20 \% \\ \text { Acer monspessulanum } & 15 \% \\ \text { Pyrus glabra } & 5 \% \\ \text { Rosa canina } & 5 \% \\ \text { Daphne mucronata } & 3 \% \\ \text { Cotoneaster nummularioides } & \\ \text { Pistacia atlantica } & 2 \% \\ \text { Astragalus caryolobus } & 4 \% \\ \text { Astragalus effusus } & \\ \text { Other species } & 1 \%\end{array}$

\section{6-Juniperus excelsa M.B.}

This community covers an area of 113.24 hectares in the south of the studies area (Fig. 1).

It is located at an altitude of $1650 \mathrm{~m}$ to $2200 \mathrm{~m}$, and its slope steepness exceedes $60 \%$ and is facing north-northeast and northwest. Its surface soil is of $35 \mathrm{~cm}$ deep with granular structure and its $\mathrm{pH}$ is 8 . In addition, soil color is reddish brown and with sandy-clay texture. Canopy cover is about $50 \%$, sand and gravel is about $40 \%$, litter around $3 \%$, clear soil about $7 \%$, altogether this type has a positive succession rate (Fig. 10). The main species of this type includes:

$\begin{array}{ll}\text { Juniperus excelsa } & 25 \% \\ \text { Acer monspessulanum } & 11 \% \\ \text { Amygdaluspabotii } & 4 \% \\ \text { Rhamnus pallasii } & 2 \%\end{array}$

\begin{tabular}{lc}
$\begin{array}{l}\text { Pistacia atlantica } \\
\text { Ferula communis }\end{array}$ & $2 \%$ \\
$\begin{array}{l}\text { Thymus kotschyanus } \\
\text { Thymus migricus }\end{array}$ & \\
$\begin{array}{ll}\text { Astragalus kabristanicus } \\
\text { Other species }\end{array}$ & $3 \%$ \\
\hline
\end{tabular}

7-Amygdalus elaeagnifolia spach. Acer monspessulanum L.sub sp. cinerascens (Boiss.) Yaltirik.

This community covers an area of 13.44 hectares in the center of the studied area (Fig. 1).

It is located at an altitude of $1700 \mathrm{~m}$ to $1900 \mathrm{~m}$, and its slope steepness ranges from $40 \%$ to $60 \%$ which is facing to the northeast. Its surface soil is of $31 \mathrm{~cm}$ deep with cubic structure and its $\mathrm{pH}$ is 7.5. In addition, soil color is dark reddish brown and with loamy-clay texture. Canopy cover is about $74 \%$, sand and gravel is about $14 \%$, litter around $4 \%$, clear soil about $8 \%$, altogether this type has a positive succession rate (Fig. 11). The main species of this type includes:

$\begin{array}{ll}\text { Amygdalus elaeagnifolia } & 36 \% \\ \text { Acer monspessulonum } & 16 \% \\ \text { Amygdaluspabatii } & 9 \% \\ \text { Juniperus excelsa } & 4 \% \\ \text { Pistacia atlantica } & 3 \% \\ \text { Cerasus microcarpa } & \\ \text { Astragalus effusus } & 4 \% \\ \text { Festuca ovina } & \\ \text { Trifolium hybridum } & 1 \% \\ \text { Other species } & 1 \%\end{array}$

\section{8-Thymus kotschyanus Boiss. - Bromus tomentellus} Boiss.

This community covers an area of 103.05 hectares from west to southwest of the studied area (Fig. 1).

It is located at an altitude of $1800 \mathrm{~m}$ to $2280 \mathrm{~m}$, and its slope steepness ranges from $40 \%$ to $60 \%$, which is facing north and northeast. Its surface soil is of $81 \mathrm{~cm}$ deep with granular structure and its $\mathrm{pH}$ is 7.9. Soil color is yellowish brown and with silty-clay texture. Canopy cover is about $56 \%$, sand and gravel is about $23 \%$, litter around $7 \%$, clear soil about $14 \%$, altogether this type has a positive succession rate (Fig. 12). The main species of this type includes:

$\begin{array}{ll}\text { Thymus kotschyanus } & 21 \% \\ \text { Bromus tomentellus } & 12 \% \\ \text { Poa bulbosa } & 7 \% \\ \text { Astragalus effusus } & 6 \% \\ \text { Acantholimon sp. } & 5 \% \\ \text { Amygdalus kotschyi } & \\ \text { Taeniatherum crinitum } & 3 \% \\ \text { Bromus tectorum } & \\ \text { Stachys lavandulifolia } & 1 \% \\ \text { Other species } & 1 \%\end{array}$


32

9- Acer monspessulanum L. subsp. cinerascens (Boiss.) Yaltirik-Amygdalus pabotii Browicz.

This community with 84.31 hectares area is located in the central part of the studied area, so it extends from the margin of Khan Valley to central parts of study are and reaches to the Ashakchi Mountain (Fig. 1).

It is located at an altitude of $1450 \mathrm{~m}$ to $1750 \mathrm{~m}$, and its slope steepness exceeds $60 \%$ and is north- and west-facing. Its surface soil is of $33 \mathrm{~cm}$ deep with cubic structure and its $\mathrm{pH}$ is 8.1. Soil color is yellowish brown and with loamysandy texture. Canopy cover is about $49 \%$, sand and gravel is about $38 \%$, litter around $5 \%$, clear soil about $8 \%$, altogether this type has a negative succession rate. The main species of this type includes:

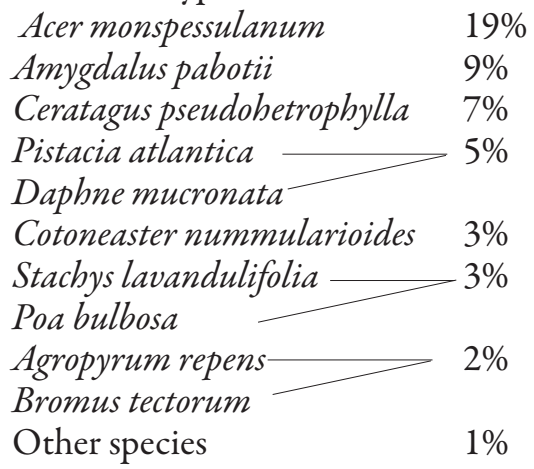

10-Hordeum bulbosum L. - Medicago sativa $L$

This community covers an area of 24.33 hectares in the northwest of the study area, ranging to Khan Valley (Fig. 1).

It is located at an altitude of $1600 \mathrm{~m}$ to $1800 \mathrm{~m}$, and its slope steepness ranges from $40 \%$ to $60 \%$ with slopes facing north and northeast. Its surface soil is of $64 \mathrm{~cm}$ deep with cubic structure and a pH of 7.6. Soil color is dark reddish brown and with loamy-clay texture. Canopy cover is about $100 \%$, sand and gravel is about $0 \%$, litter around $0 \%$, clear soil about $0 \%$, altogether this type has a positive succession rate (Fig. 13). The main species of this type includes:

$\begin{array}{ll}\text { Hordeum bulbosum } & 33 \% \\ \text { Medicago sativa } & 23 \% \\ \text { Trifolium pratense } & 14 \% \\ \text { Vicia villosa } & 6 \% \\ \text { Phlomis tuberosa } & 4 \% \\ \text { Astragalus mollis } & 7 \% \\ \text { Bromus danthoniae } & \\ \text { Festuca ovina } & 6 \% \\ \text { Thymus kotschyanus } & 5 \% \\ \text { Secale montanum } & \\ \text { Other species } & 2 \%\end{array}$

11- Salix alba L. - Juglans regia $L$.

This community covers an area of 7.82 hectares in the north of the studied area in margin of Khan Valley (Fig. 1). It is located at an altitude of $1420 \mathrm{~m}$, and its slope steepness ranges from $0 \%$ to $10 \%$. Its surface soil is of $90 \mathrm{~cm}$ deep with granular structure which is firm and its $\mathrm{pH}$ is 7.8. Soil color is yellowish brown and with loamy texture. Canopy cover is about $85 \%$, sand and gravel is about $7 \%$, litter around $4 \%$, clear soil about $4 \%$, altogether this type has a positive succession rate. The main species of this type includes:

$\begin{array}{ll}\text { Salix alba } & 40 \% \\ \text { Juglans regia } & 33 \% \\ \text { Fraxinus rotundifolia } & 4 \% \\ \text { Elaeagnus angustifolia } & 3 \% \\ \text { Rhus coriaria } & 2 \% \\ \text { Other species } & 3 \%\end{array}$

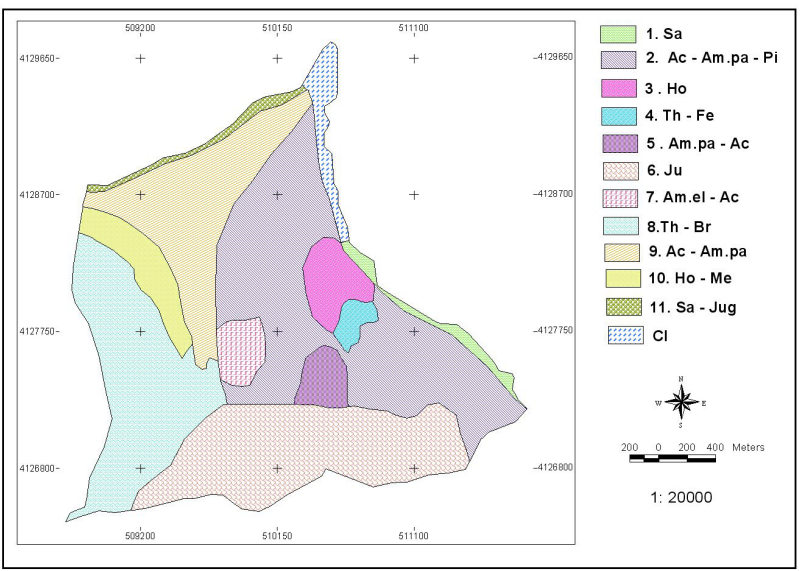

Fig. 1. Coloured vegetation map of study area

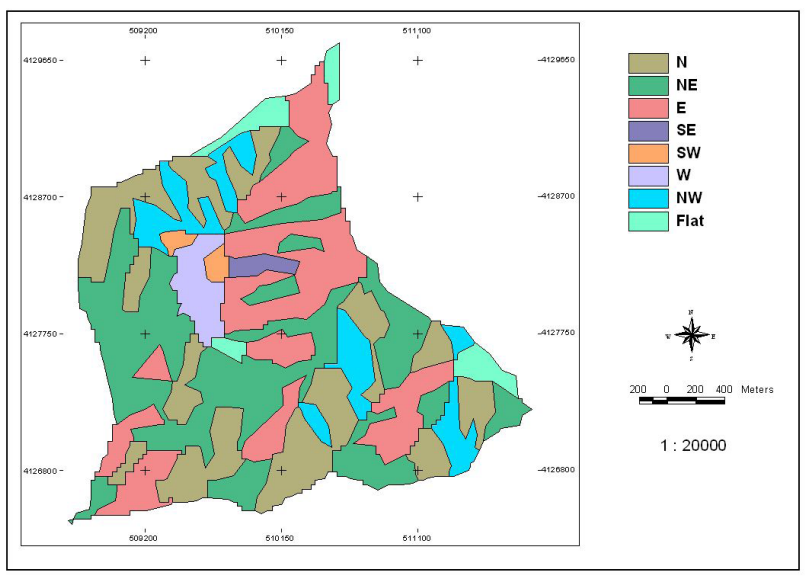

Fig. 2. Slopes facing map of study area 


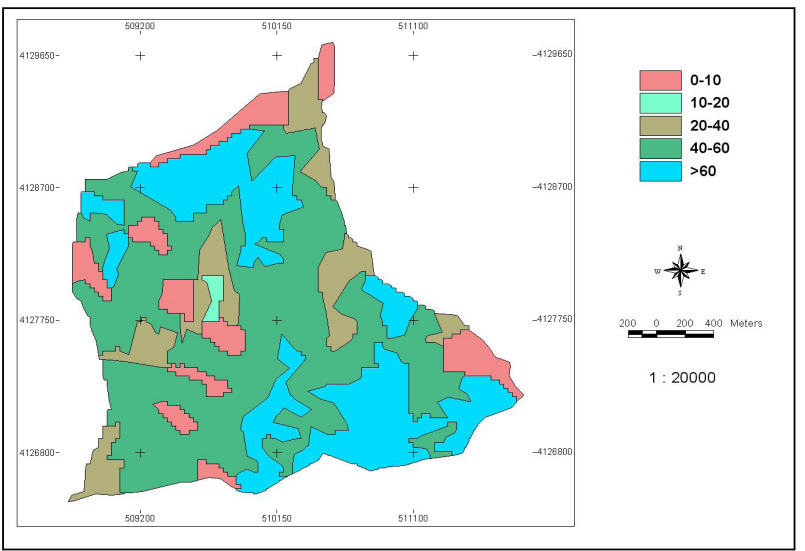

Fig. 3. Slopes steepness map of study area

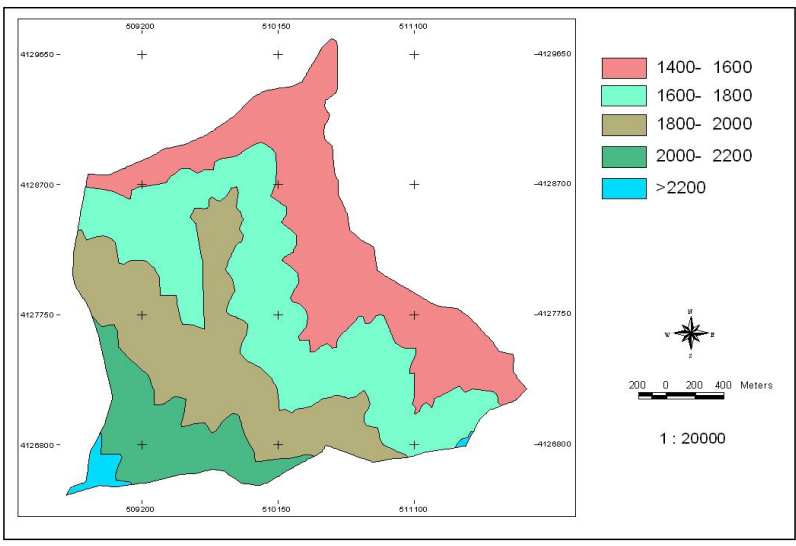

Fig. 4. Hypsometric map of study area

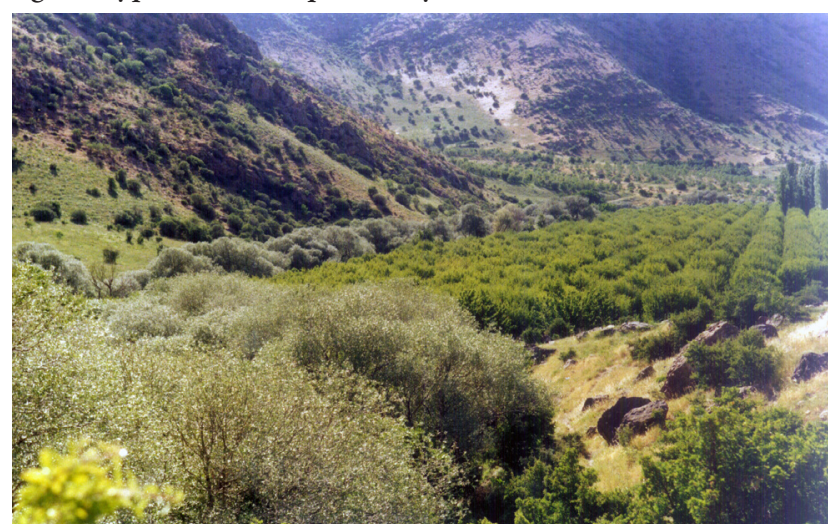

Fig. 5. Salix community

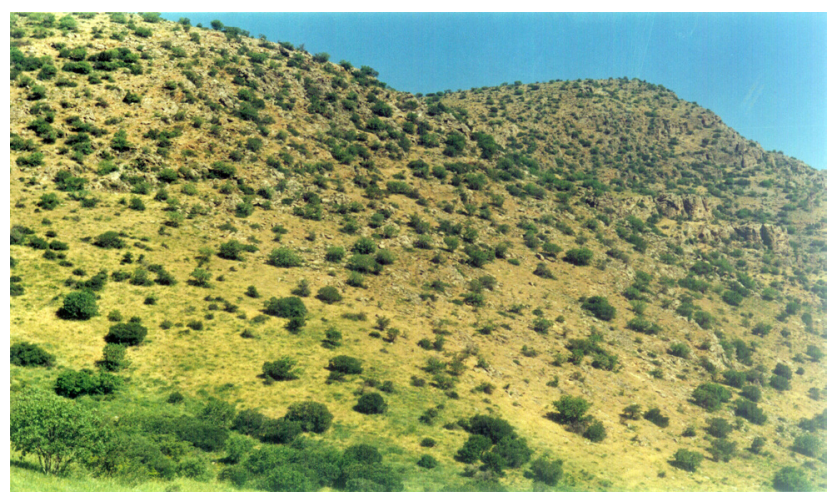

Fig. 6. Acer-Amygdalus pabotii-Pistacia community

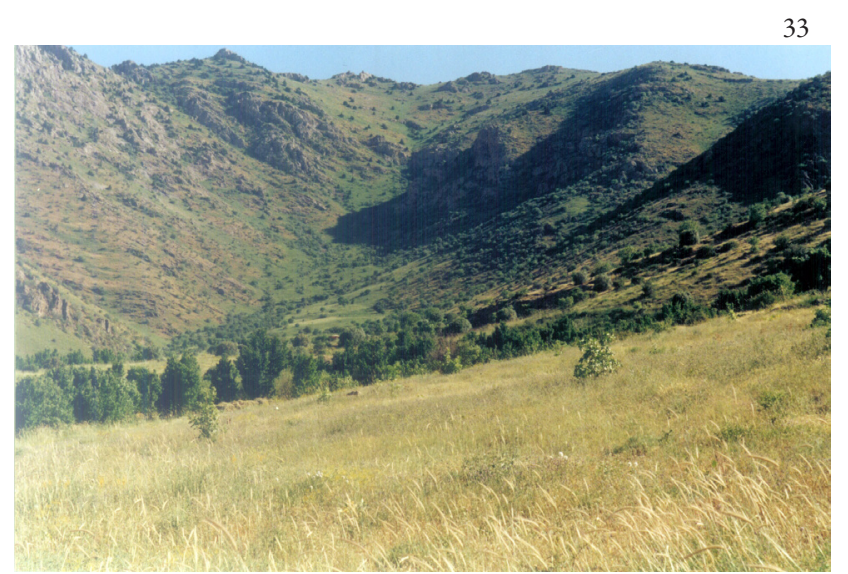

Fig. 7. Hordeum community

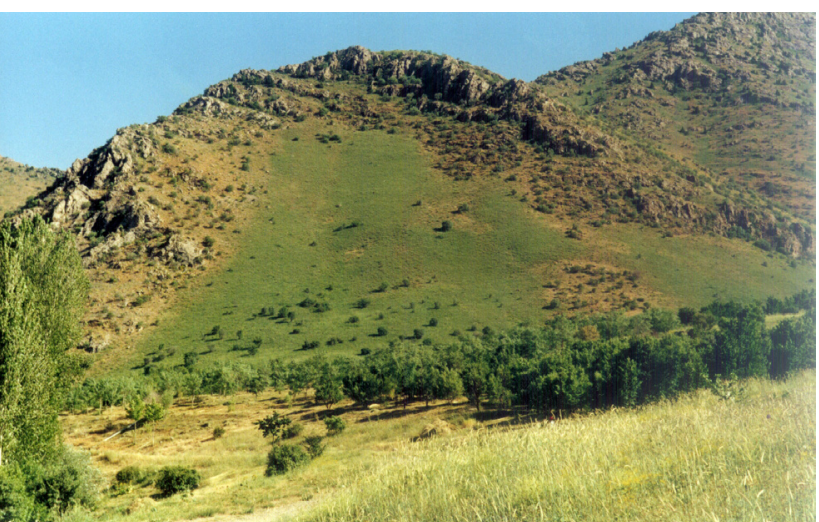

Fig. 8. Thymus-Festuca community

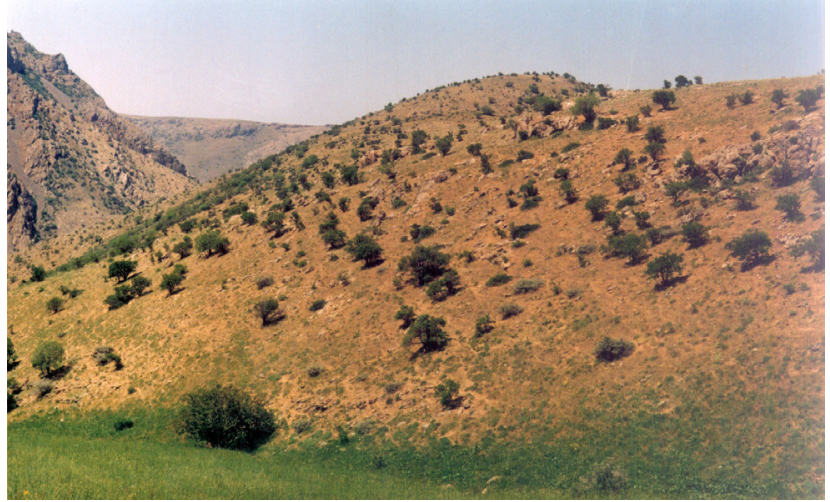

Fig. 9. Amygdalus pabotii-Acer community

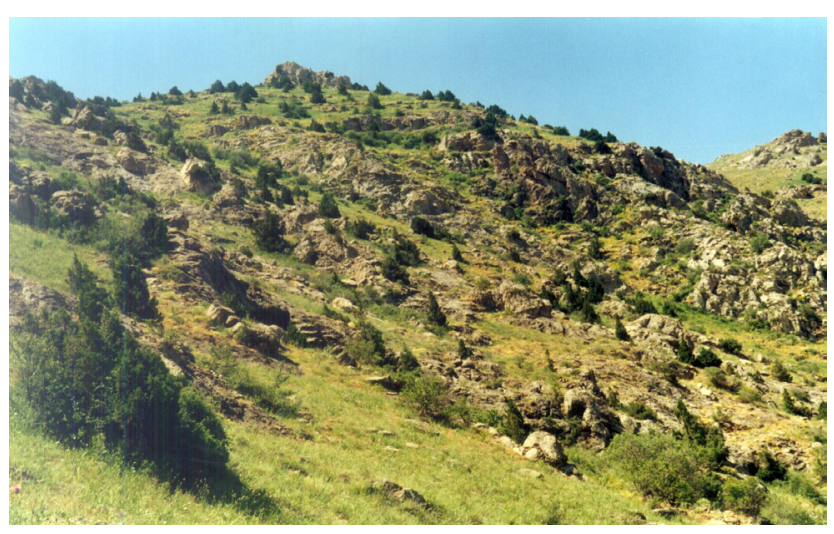

Fig. 10. Juniperus community 


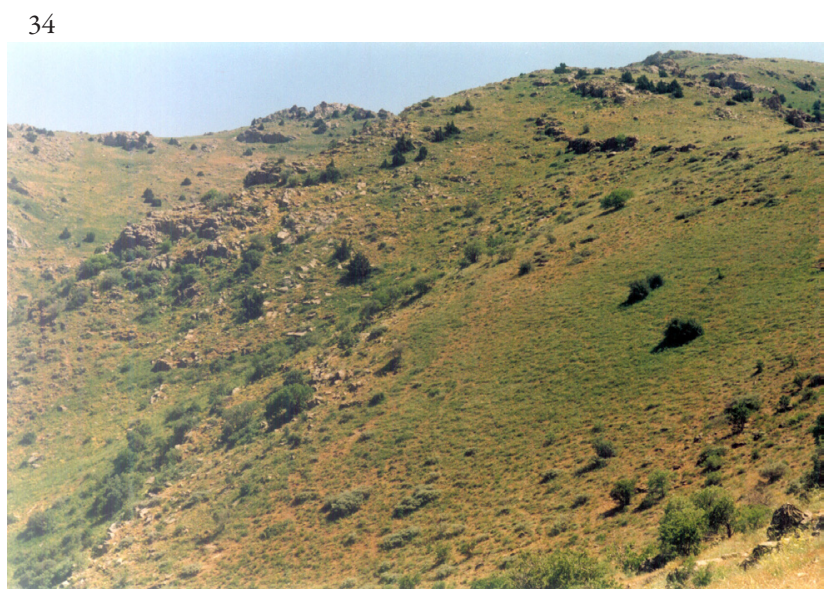

Fig. 11. Amygdalus elaeagnifolia-Acer community

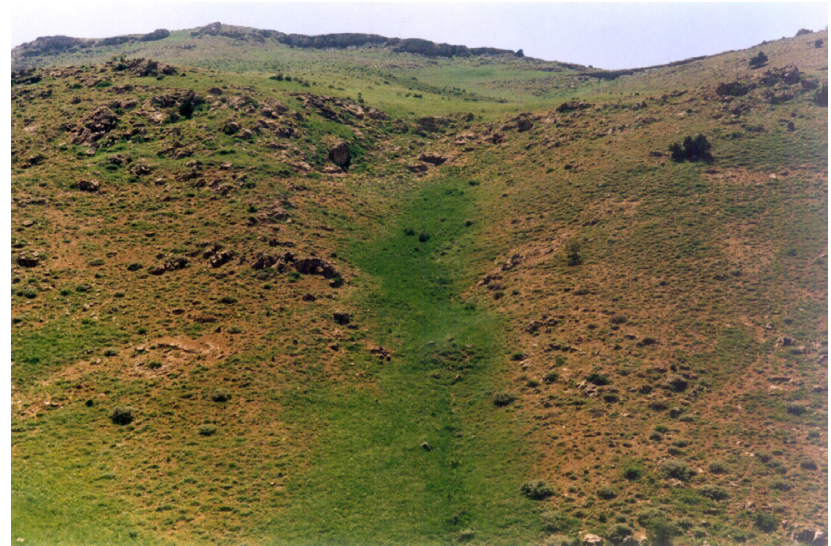

Fig. 12. Thymus-Bromus community

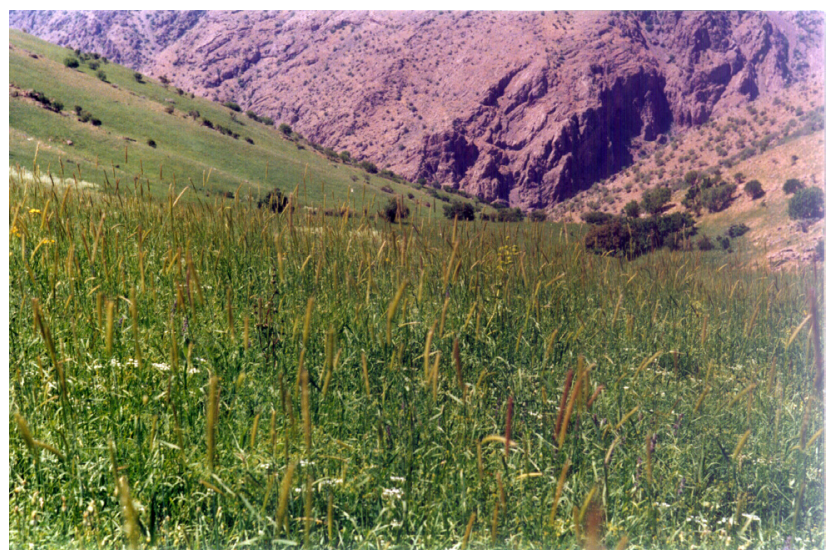

Fig. 13. Hordeum-Medicago community

\section{Conclusions}

By investigating the effects of ecological factors including altitude, slope steepness, slope direction, soil and biologic on plant communities the study resulted to following results:

1) Altitude:

Altitude is known as one of the most influencing factors on plant distribution. Some plants don't like the high altitudes because of low temperatures and shortage of growth period, and existence of severe winds in mountains also limits plant growth.

The studied area includes Salix alba community at an $1420 \mathrm{~m}$ altitude along the main river, Juniperus extended in $1650 \mathrm{~m}$ to $2200 \mathrm{~m}$, and Thymus-Bromus at $1800 \mathrm{~m}$ to 2280 m. Edisho (1998), in Khoy-Salmas area introduced the Juniperus community at $2400 \mathrm{~m}$ to $2700 \mathrm{~m}$. Naseri et al. (2002) reported the existence of the same community at $1500 \mathrm{~m}$ to $2650 \mathrm{~m}$. Thymus-Artemisia community is seen by Aleyha and Shokuii (2003) at $2350 \mathrm{~m}$ to $2500 \mathrm{~m}$ height in Semnan. Karimi (1997) recognized the ThymusAgropyron community in Anzali-Khalkhal area at 1400 m-1800 m height.

2) Slope direction:

Slope direction is also known as one of the most important factors which affect plant distribution. North and south facing slopes have fully different vegetation covers. South facing slopes, because of intensive solar radiation, high temperature in comparison with north facing slopes have low humidity. In contrast, north facing slopes have low temperature and low radiation, has high humidity. As the Juniperus community is dominant in north facing slopes, and its lower limit is extended to $1650 \mathrm{~m}$ height, such a situation is resulted from the deficit of temperature and deficit of radiation. Thymus-Bromus and Thymus-Festuca is also dominant in north facing slopes.

Nazarian (2003), in Central Alborz, indicated the Salix community in north-northeast facing slopes, and the thorny assemblages on south, southwest, southeast, north and northwest and northeast slopes facing. In addition, Ghelichnia (1999) in Nardin region, Dianatnajad and Slami (1996) in Thouran reserve indicated the effect of slope direction in plant communities' distribution.

3) Slope steepness:

Slope steepness affects the vegetation cover on slopes. In the studied area salix community as a tree assemblage are located on gentle slopes, but Juniperus and AcerAmygdalus communities are extended on steep slopes. Khageaddin (2000) in Kolah ghazi National Park reported the existence of Amygdalus, Amygdalus haussknechtii on high slopes of more than 100\%. Jafari Kokhdan(2001) in Dena region indicated the Salicetum excelsae on gentle slopes. Nazarian (2003) in Central Alborz, reported tree assemblages on gentle slopes. Vakili (1988), in Shahrebabak, indicated Amygdalus community on gentle and steep slopes.

\section{4) Soil texture:}

Soil texture is also important for planning distribution. In the studied area Salix is found on sandy-clay and loamy soils. Hordeum and Hordeum-Medicago are extended on soils with out sand and gravel. Also, in the studied area, Hordeum from Hordeum-Medicago and Thymus-Festuca from Thymus-Bromus and Amygdalus-Acer from AcerAmygdalus are separated by soil texture.

Nazarian (2003) reported the Salix community on sandy-clay and loamy soils, Batoli (1997), indicates the 
Amygdalus community on clay-loamy soils, and Masoomi (1993), also reports the Amygdalus community on clayloamy soil.

\section{References}

Aleyha, M. and M. Shokuii (2003). Vegetation types of Semnan area. Researchs Institute of Forests and Rangelands, Tehran, No. 335.

Asri, Y. (1995). Phytocociology.publishing Researchs Institute of Forests and Rangelands, Tehran. 134:285.

Batuli, H. (1997). Phytocociology of west region of abeshirin in kashan. Ms Thesis, Tehran university, Iran, 198p.

Braun-Blanquet, J. (1932). Plant Sociology, the study of plant commuities (Translation of pflanzensoziologie by Fuller, G.D. and Conard, H. S. 1983) Mc Graw Hill Book company, Inc., New York. 433p.

Dianatnajad, H. and B. Slami Jadidi. (1996). Investigation of vegetation growth and developing plant map of the part of Touran reserve. The Iranian Journal Biology. 3:243-267.

Eshghi Malayeri, B. (1984). Investigation of the vegetation cover of protected area of Haftad Gholeh. Ms Thesis, Sciences Faculty, Tehran University.

Fallah, S. (1999). Investigation of the vegetation cover of protected area of Mute in north west of Isfahan. Ms Thesis, Sciences Faculty, Isfahan University.

Ghelichnia, H. (1999). Evaluation of correlation coefficients plant communities with topographical factors (slope \& direction) in Nardin area. The Iranian Journal Pajouhesh \& Sazandegi. 43:33-37.

Hamzeh, B. (1995). Plant communities of Gheshm Island and their relation to ecological factors and providing vegetation map, Ms thesis, Tehran University.

Jafari Kokhdan, A. (2002). Eco-phytosociological evaluation of vegetation cover of Dena. PhD Thesis, Sciences Faculty, Tehran University, 289p.

Karimi, Gh. H. (1997). Vegetation cover of Anzali-Khalkhal area. Researchs Institute of Forests and Rangelands, Tehran. 170.

Khageaddin, H. (2000). Phytocociology of Kolahghazi National Park. The Iranian Journal Pajouhesh \& Sazandegi. 45:1016.
Masoomi, M. (1993) Floristic study, vegetation cover analysis and plant map developing in east Tafresh. Ms Thesis, Sciences Faculty, Tehran University.

Mirtajeddini, M. (1996). Floristic studies and Phytosociology of Cheshme sabz region in Baft. Ms Thesis, Sciences Faculty, Tehran University, 184p.

Mirjalili, A. (1997). Phytosociology of Harat and Marvast of Yazd. Ms Thesis, Sciences Faculty, Tehran University, 121p.

Mohebbi, F. (1997). Phytosociology of Sier mountain, Urmia, Ms Thesis, Sciences Faculty, Tehran University, 150p.

Mehrnia, M., Y. Asri and H. Amiri (2003). Investigation the plant communities of protected area in north east in Khorramabad. 11 National congress of Biology, Urmia University, Iran.

Muller-Dombois, D. and H. Ellenberg (1974). Aims and methods of vegetation ecology. John Wiley \& Sons Inc., New York, 547p.

Naseri, A., A. Purmirzaii, Gh. Tajeddini and N. Arabzadeh (1999). Vegetation cover of Sirjan area. Researchs Institute of Forests and Rangelands, Tehran, 226.

Naseri, A., A. Purmirzaii and N. Arabzadeh (2002). Vegetation types of Sabzevaran area.Researchs Institute of Forests and Rangelands, Tehran, 308.

Nazarian, H. (2003.) Eco-Phytosociological evaluation of Elika and Dona Watershed of central Alboorz. PhD Thesis, sciences Faculty, Tehran University.

Odisho, S. (1998). Vegetation cover of Khoy-Salmas area. Researchs Institute of Forests and Rangelands, Tehran, 205.

Taimurzadeh, A., M. Akbarinia, M. Hosaini and M. Tabari (2003). Phytosociology of Forests in eastern Ardabil. Iranian Journal Agriculture Sciences and Natural Sources.

Vakili Shahrebabaki, M. (1988). Floristic study, vegetation cover analysis in plain and Forested parts of Shahrebabak. Ms Thesis, Tehran University, 75p. 